\title{
NOTES ON AND DESCRIPTIONS OF SPHINGIDAE.
}

\author{
By Dr. Karl Jordan. \\ (With six text-figs.)
}

\section{Polyptychus paupercula senniger subsp. nov. (text-fig. 1).}

§. A P. p. paupercula Holl. (1889), armatura genitali distinguendus : harpa leviter trilobata.

Hab. Bingerville, Ivory Coast, June, August, and September-October,

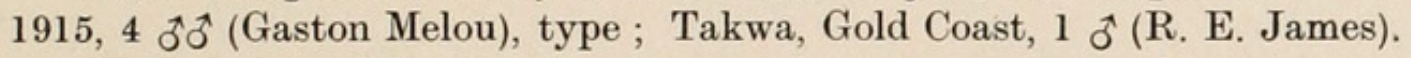

There are no differences in colour and pattern between the specimens from the districts Senegal-Niger and Niger-Congo. All 5 ธึ $\sigma^{*}$ we have from the former district, though differing slightly inter se in the shape of the harpe, are distinguished from the more southern subspecies in the apical margin of the harpe being bisinuate; the lower sinus is narrow and fairly deep, while the upper sinus is shallow (text-fig. 1).

\section{Polyptychus molitor R. \& J. (1912) (text-figs. 2, 3).}

We described this species from some of in the collection of the British Museum obtained by H. A. Foy at Ibi on the River Benue, Nigeria ; cf. Novitates Zoologicae, xix. p. 132, no. 4 (1912). The Tring Museum has since received

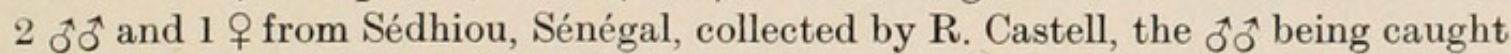
in October 1917 and the $q$ dated simply 1917.

The $\hat{\sigma}$ is smaller than the $q$; the forewing is narrower, its distal margin more oblique; with the apex more produced. Antenna stouter than in $ᄋ$, seriated cilia longer, otherwise similar to that of the + . Palpi larger than in the $q$, joint closed, third segment small in both sexes (not two-thirds of second as stated in the original description), second segment a little longer than wide measured to the base of the third (i.e. exclusive of the apical scaling).

Tenth tergite (text-fig. 2) very hairy, broad, divided by a rounded sinus into two sharply pointed processes; tenth sternite represented by a low membranous ridge. Clasper without friction-scales, deeply concave on the inner side, the ventral margin elevate; above this ridge, in the cavity, a second ridge, the two ridges uniting distally and forming a large, pointed, conical process placed about halfway between dorsal and ventral margins and being almost vertical upon the plane of the clasper, leaning a little proximad (text-fig. 3). Apical portion of clasper weakly chitinised, nearly membraneous, clothed with long scales. Penis-funnel cylindrical, longer than broad ; penis-sheath also cylindrical, slightly widened at the apex, without armature.

\section{Polyptychus orthographus R. \& J. (1903).}

We have now a specimen of the + , from Luluaburg, Kassai, Congo. It agrees in markings with the $\delta$, but is much darker both above and beneath. The distal margin of the forewing is convex, with the apex projecting, the marginal area being wider than in the $\delta$. The antenna bears prolonged seriated cilia, but the lateral grooves are indistinct, and the segments have a straight ventral. outline (lateral aspect). 


\section{Polyptychus reussi Strand (1911).}

Our statement in Novitates Zoologicae, xxiii. p. 260, no. 23 (1916), that in Strand's description the costal margin of the forewing below is said to be

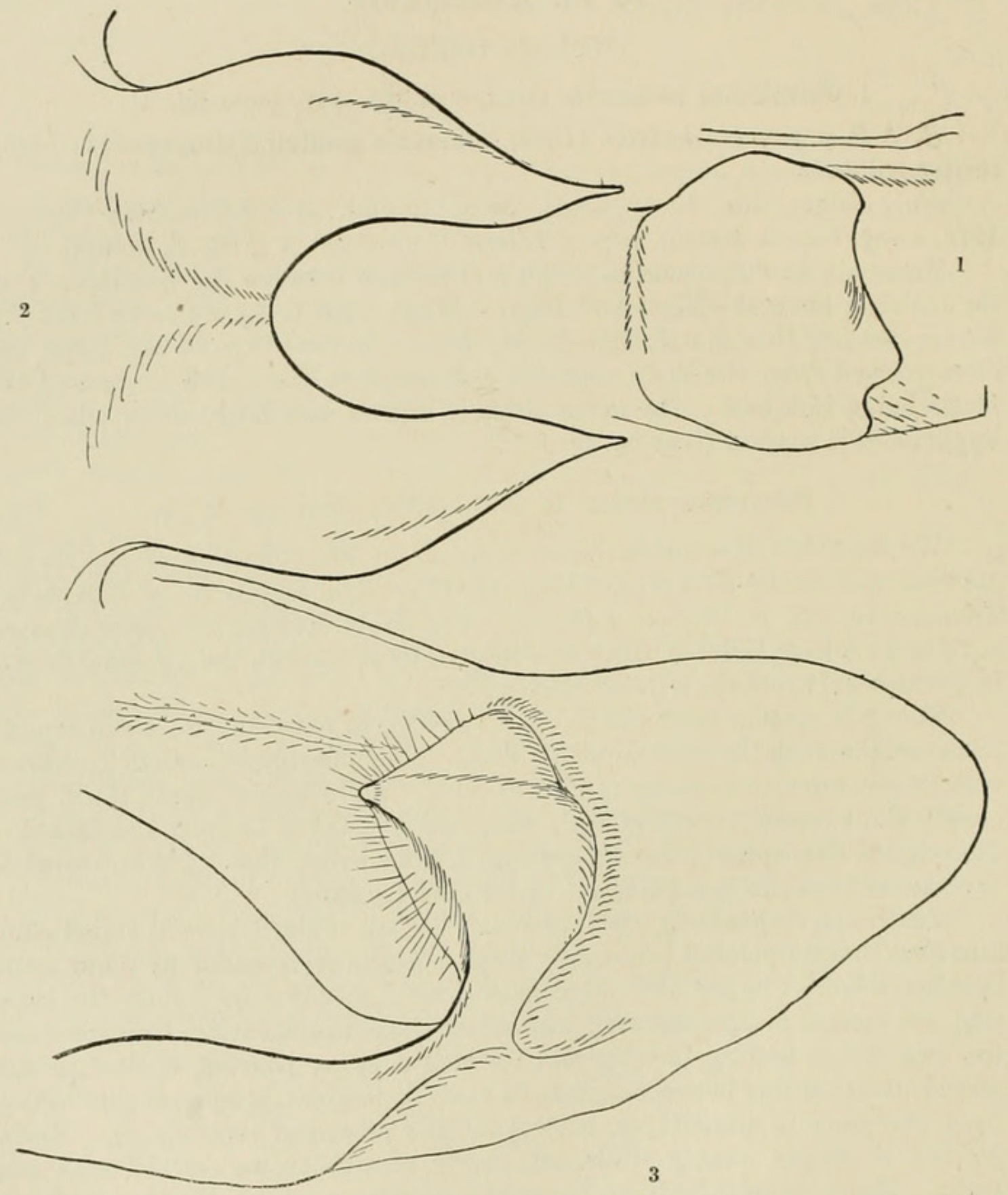

Fic. 1.-Polyptychus paupercula senniger, $\hat{\sigma}$; harpe.

Fra. 2.-Polyptychus molitor, $\delta$; anal tergite.

Fig. 3.-Polyptychus molitor, ơ ; clasper.

dark red is erroneous. I misread the description, which agrees with the $q$ of $P$. coryndoni R. \& J. (1903). Strand's name, therefore, is a synonym.

5. Temnora nitida spec. nov. (text-figs. 4, 5, 6).

o. Cervina; alis anticis fascia olivacea fere recta oblique a costa ad marginem exteriorem extensa extus luteo marginata ornatis atque lineis trans- 
versis e lunulis olivaceis compositis signatis; posticis aurantiaco-rufis, fascia marginali brunnescente. Infra rufo-avellina, lineis e lunulis et angulis parvis compositis olivaceis notata.

Long. al. ant. $26 \mathrm{~mm}$., lat. $11.5 \mathrm{~mm}$.

$H a b$. Diégo Suarez, N.E. Madagascar, December 1916 (G. Melou) ; 3 $\widehat{\delta}$. In the bright rufous hindwing this new Temnora resembles $T$. elegans Roths. (1894), but the oblique band of the forewing distinguishes nitida at once from that species.

Body fawn-colour, abdomen more rufescent; the scales on the thorax above

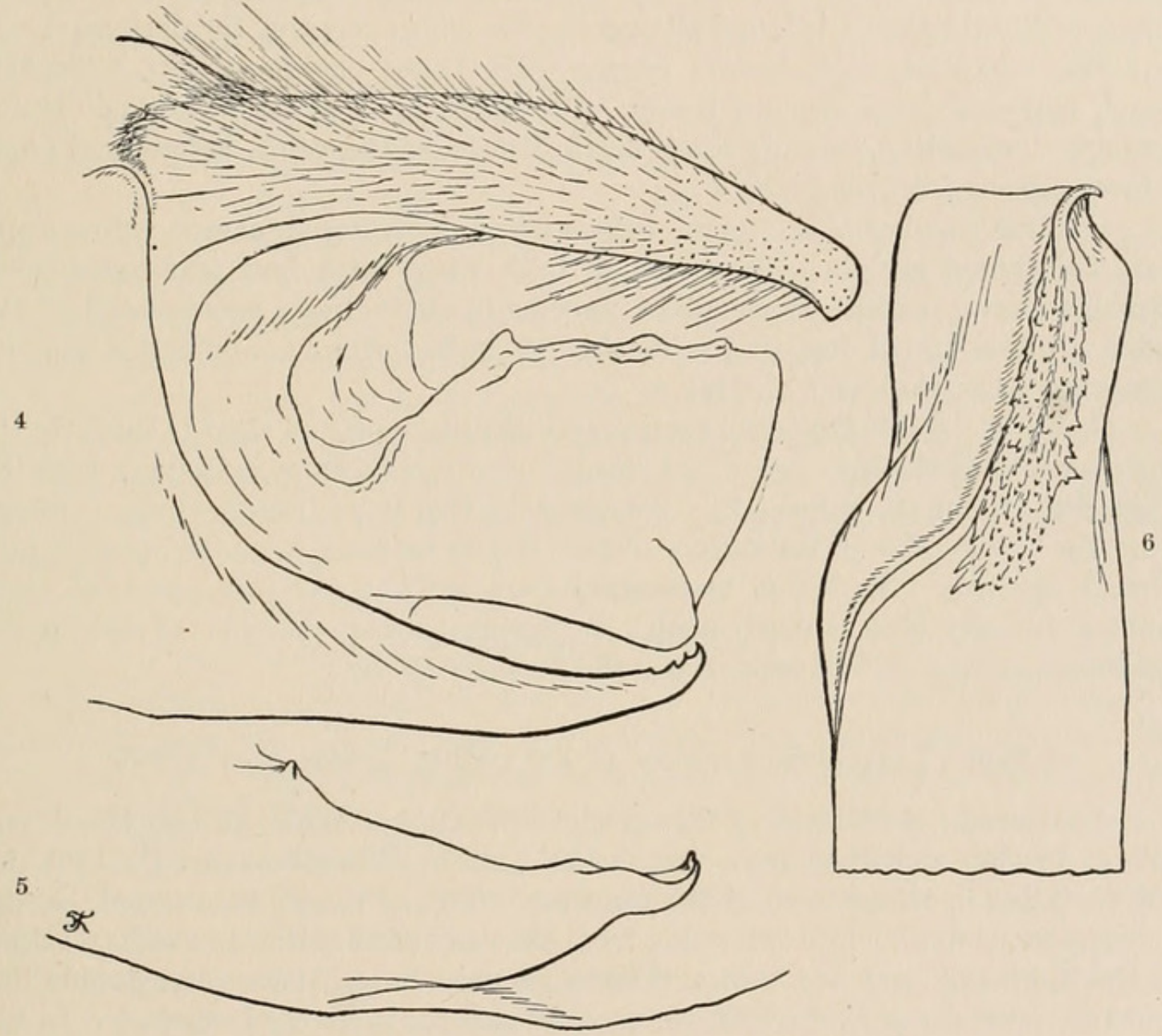

FIG. 4.-Temnora nitida, ô ; anal segment, lateral view.

Fig. 5.-Temnora nitida, ô; harpe.

FIG. 6.-Temnora nitida, $\delta$; penis-sheath.

and beneath and on the upperside of the head pale-tipped ; underside rufescent, somewhat paler than upper. An ill-defined line above eye, another on second palpal segment likewise diffuse and inconspicuous, and scales at joint between first and second palpal segment creamy; abdomen beneath with two rows of olive-black dots; foretibia externally deep fawn-colour.

Wings, above.—-Forewing fawn-colour, outer margin evenly rounded-convex in middle, concave anteriorly and posteriorly, not crenulate; a well-defined olive band runs from the middle of the costal margin to below middle of outer margin, about $1.5 \mathrm{~mm}$. broad anteriorly, widening distally and here shading off . to anal angle, on the distal side the band bounded by a pale line, which varies 
in distinetness ; in basal half two pairs of transverse excurved lines, olivaceous, somewhat scalloped and more or less interrupted at the veins, the proximal pair rather indistinct, the second pair about $7.5 \mathrm{~mm}$. from base at costa and $6 \mathrm{~mm}$. at hindmargin; on disc a third pair, crenulate, extending from costa beyond band to hindmargin $11 \mathrm{~mm}$. from base, excurved anteriorly and somewhat incurved posteriorly, i.e. slightly S-shaped; further distally another pair, more or less indistinct ; the costal portions of the discal lines form a darkish triangular patch distally to the band, the base of the patch at the costa being about as long as the distance from the apex of the wing; below apex a marginal luniform pale olive spot bounded proximally by purplish fawn scaling; such scaling, which is slightly glossy, is found all over the forewing excepting the dark markings and the subapical, sepia-brown, area.-Hindwing orange-rufous; a darker, hazel, marginal band about $2.5 \mathrm{~mm}$. wide below apex at its widest point, not strongly contrasting, bearing small black dashes on the veins, before anal angle a fawn-coloured diffuse patch.

Underside duller than upper, rufous-hazel, forewing cinnamon-rufous from base to beyond middle; outer half of both wings with four transverse lines, blackish above, dentate or crenulate, varying in distinctness, accentuated on the veins ; below tip of forewing a blackish marginal cloud; abdominal area of hindwing paler than rest of wing.

Genitalia: both the tenth tergite and sternite long and slender (text-fig. 4), the former with the tip convex and entire; the sternite more acuminate with the apex dentate on the upperside. Clasper with five large friction-scales. Harpe (text-fig. 5) lying flat on the surface of the clasper, tapering, with the apex slightly turned upwards. Sheath of ejaculatory duct with an elongate patch of teeth ending apically with a small hook; a swelling along the side of the patch continues proximad half around the sheath (text-fig. 6).

\section{Some Individual varieties of Xylophanes turbata Edw. (1887).}

A series of $1 \delta^{\pi}$ and 8 우 of this species from Orange Walk, British Honduras, caught in May and June 1917, recalls the Eastern Hippotion velox F. (1793) by the variation in the pattern of the forewing. Two of the fo are normal, having a conspicuous double line extending from the apex of the wing to the basal third of the hindwing, and five thin and inconspicuous lines between the double line and the outer margin, of which the most distal one is barely indicated. In the $\delta$ and one $q$ of the above series the double line is represented by a single thin line (corresponding to the outer line of the pair) and the following line is scarcely traceable. In the remaining 5 우 the double line has more or less completely disappeared, excepting a dash at the wing-apex, which the other lines join. The brown cloud distally to the apex of the cell is distinct in all the specimens. 


\section{$2 \mathrm{BHL}$ Biodiversity Heritage Library}

1920. "Notes on and descriptions of Sphingidae." Novitates zoologicae : a journal of zoology in connection with the Tring Museum 27, 159-162. https://doi.org/10.5962/bhl.part.7301.

View This Item Online: https://www.biodiversitylibrary.org/item/22600

DOI: https://doi.org/10.5962/bhl.part.7301

Permalink: https://www.biodiversitylibrary.org/partpdf/7301

\section{Holding Institution}

Natural History Museum Library, London

\section{Sponsored by}

Natural History Museum Library, London

\section{Copyright \& Reuse}

Copyright Status: In copyright. Digitized with the permission of the rights holder.

Rights Holder: The Trustees of the Natural History Museum, London

License: http://creativecommons.org/licenses/by-nc-sa/4.0/

Rights: http://biodiversitylibrary.org/permissions

This document was created from content at the Biodiversity Heritage Library, the world's largest open access digital library for biodiversity literature and archives. Visit BHL at https://www.biodiversitylibrary.org. 